\title{
PROPHYLACTIC LASER PHOTOCOAGULATION IN STICKLER SYNDROME
}

\author{
HANA LEIBA, MOSHE OLIVER ${ }^{1}$ and AYALA POLLACK ${ }^{1}$ \\ Rehovot, Israel
}

\begin{abstract}
SUMMARY
The ocular manifestations in a family with Stickler syndrome and the results of laser photocoagulation as preventive treatment for retinal detachment are described. Forty-two family members with Stickler syndrome were retrospectively reviewed; 22 had ocular abnormalities, 22 had myopia and 16 had high myopia. Ten patients had developed retinal detachment and 9 of them were blind in one or both eyes because of irreparable detachment. Only 2 eyes had been operated on successfully. Ten eyes were lasered prophylactically. In eyes with extensive vitreoretinopathy laser burns were applied $360^{\circ}$ around the peripheral retina at the border between the pathological and normal retina. Eyes with isolated lesions received focal treatment around the pathological areas. Four eyes received $360^{\circ}$ laser photocoagulation and 6 eyes received focal treatment. Of the treated cases, 9 retinas remained attached for a follow-up period ranging from 1 to 15 years. One patient was lost to follow-up, and 5 years later developed retinal detachment in one eye from a new non-lasered lesion. In conclusion, in this particular family the incidence of retinal detachment was significantly higher in non-lasered eyes than in lasered eyes $(p<0.025)$.
\end{abstract}

Hereditary progressive arthro-ophthalmopathy, known as Stickler syndrome, is an autosomal dominant hereditary connective tissue disorder characterised by ocular, orofacial and skeletal manifestations..$^{1-8}$ One of the more difficult ocular therapeutic problems in this group of patients is the high incidence of retinal detachment (approximately $50 \%$ of affected individuals) with poor surgical results, ${ }^{5}$ often in young patients. Although there is no clear consensus as regards prophylactic treatment, most clinicians are rather liberal and recommend

From: Department of Ophthalmology, Kaplan Hospital, Rehovot, Israel. ${ }^{1}$ Affiliated to the Medical School of the Hebrew University-Hadassah, Jerusalem, Israel.

Correspondence to: A. Pollack, MD, Department of Ophthalmology, Kaplan Hospital, 76100 Rehovot, Israel. Fax: 972-8410991. prophylactic treatment of all new tears, and many recommend treatment of all areas of lattice or latticelike degeneration. ${ }^{6.9}$ Treatment modalities include scleral buckle, diathermy, cryotherapy and laser photocoagulation. ${ }^{6.9}$ On the basis of our previous experience ${ }^{10-12}$ we chose to perform argon laser photocoagulation as a prophylactic treatment in 10 eyes of 6 family members with Stickler syndrome, all of whom showed signs of progressive peripheral retinal degeneration. Here we describe the ocular manifestations, the lasering techniques used and their results.

\section{FAMILY DATA}

The 42 family members included in this study spanned four generations (Fig. 1). There was no consanguinity in any couple. Family members who were deceased or living in another country were included only if a definite history of their ocular status could be obtained.

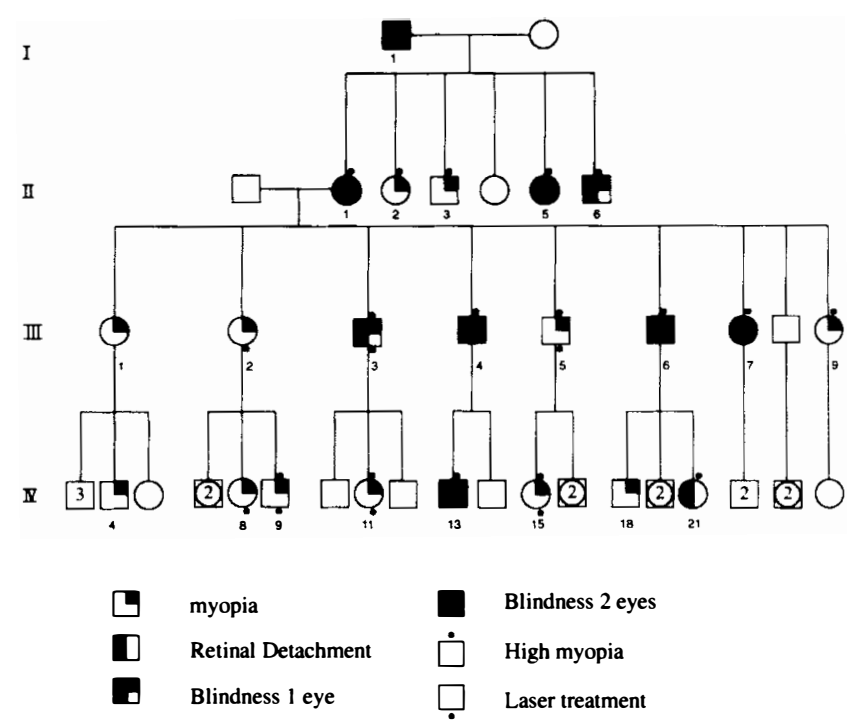

Fig. 1. Pedigree of family. Squares, male subjects; circles, female subjects. 
Table I. Ocular data of affected family members

\begin{tabular}{|c|c|c|c|c|c|c|c|c|c|c|c|c|}
\hline \multirow[b]{2}{*}{$\begin{array}{l}\text { Case } \\
\text { no. }\end{array}$} & \multirow[b]{2}{*}{$\begin{array}{c}\text { Family } \\
\text { member/sex }\end{array}$} & \multicolumn{5}{|c|}{ Ocular findings } & \multirow[b]{2}{*}{$\begin{array}{c}\text { Laser } \\
\text { photoco- } \\
\text { agulation }\end{array}$} & \multicolumn{2}{|c|}{ Final anatomical results } & \multicolumn{3}{|c|}{ Final visual results } \\
\hline & & Myopia $^{a}$ & $\begin{array}{c}\text { High } \\
\text { myopia }^{b}\end{array}$ & $\begin{array}{l}\text { Vitreous } \\
\text { degenera- } \\
\text { tion }\end{array}$ & $\begin{array}{l}\text { Retinal }^{\mathrm{d}} \\
\text { pathology }^{\text {atholo }}\end{array}$ & $\begin{array}{c}\text { Retinal } \\
\text { detachment }\end{array}$ & & $\begin{array}{l}\text { Attached } \\
\text { retina }\end{array}$ & $\begin{array}{l}\text { Detached } \\
\text { retina }\end{array}$ & Good $^{e}$ & Poor $^{\mathrm{f}}$ & Blindness $^{\mathrm{g}}$ \\
\hline 1 & $\mathrm{I}-1 / \mathrm{M}$ & \multicolumn{3}{|c|}{ Unknown } & &.$+ \mathrm{OU}$ & & &,$+ \mathrm{OU}$ & & &.$+ \mathrm{OU}$ \\
\hline 2 & $\mathrm{II}-1 / \mathrm{F}$ & & + & + & + &,$+ \mathrm{OU}$ & & &.$+ \mathrm{OU}$ & & &,$+ \mathrm{OU}$ \\
\hline 3 & $\mathrm{II}-2 / \mathrm{F}$ & & + & + & & & &,$+ \mathrm{OU}$ & &.$+ \mathrm{OU}$ & & \\
\hline 4 & II-3/M & & + & + & & & &.$+ \mathrm{OU}$ & &.$+ \mathrm{OU}$ & & \\
\hline 5 & II-5/F & & + & + & + &,$+ \mathrm{OU}$ & & &,$+ \mathrm{OU}$ & & &,$+ \mathrm{OU}$ \\
\hline 6 & II-6/M & & + & + & + &,+ 1 eye & &,+ 1 eye &,+ 1 eye & &,+ 1 eye &,+ 1 eye \\
\hline 7 & III- $1 / \mathrm{F}$ & + & & + & & & & & &,$+ \mathrm{OU}$ & & \\
\hline 8 & III-2/F & + & & + & + & &.$+ \mathrm{OU}$ & & &,$+ \mathrm{OU}$ & & \\
\hline 9 & III-3/M & & + & + & + &,$+ \mathrm{OU}$ & &,+ 1 eye &,+ 1 eye & &,+ 1 eye &,+ 1 eye \\
\hline 10 & III-4/M & & + & + & + &.$+ \mathrm{OU}$ & & &,$+ \mathrm{OU}$ & & &,$+ \mathrm{OU}$ \\
\hline 11 & III-5/M & & + & + & + &,+ 1 eye &,$+ \mathrm{OU}$ &.$+ \mathrm{OU}$ & &,+ 1 eye &,+ 1 eye & \\
\hline 12 & III-6/M & & + & + & + &,$+ \mathrm{OU}$ & & &,$+ \mathrm{OU}$ & & &,$+ \mathrm{OU}$ \\
\hline 13 & III-7/F & & + & + & + &,$+ \mathrm{OU}$ & & &.$+ \mathrm{OU}$ & & &,$+ \mathrm{OU}$ \\
\hline 14 & III-9/F & & + & + & & & &,$+ \mathrm{OU}$ & &.$+ \mathrm{OU}$ & & \\
\hline 15 & IV-4/M & + & & + & + & & &,$+ \mathrm{OU}$ & &.$+ \mathrm{OU}$ & & \\
\hline 16 & IV-8/F & + & & + & + & &,+ 1 eye &,$+ \mathrm{OU}$ & &.$+ \mathrm{OU}$ & & \\
\hline 17 & IV-9/M & & + & + & + & &,+ 1 eye &,$+ \mathrm{OU}$ & &.$+ \mathrm{OU}$ & & \\
\hline 18 & IV-11/F & & + & + & + & &,$+ \mathrm{OU}$ &,$+ \mathrm{OU}$ & &.$+ \mathrm{OU}$ & & \\
\hline 19 & IV-13/M & & + & + & + &,$+ \mathrm{OU}$ & & &.$+ \mathrm{OU}$ & & &,$+ \mathrm{OU}$ \\
\hline 20 & IV $-15 / \mathrm{F}$ & & + & + & + & &,$+ \mathrm{OU}$ &.$+ \mathrm{OU}$ & &.$+ \mathrm{OU}$ & & \\
\hline 21 & IV-18/M & + & & + & & & &,$+ \mathrm{OU}$ & &,$+ \mathrm{OU}$ & & \\
\hline 22 & IV-21/F & & + & + & + &,+ 1 eye & &,$+ \mathrm{OU}$ & & +.1 eye &,+ 1 eye & \\
\hline
\end{tabular}

OU, both eyes.

${ }^{a}$ Myopia of spherical equivalent of less than 6 dioptres; ${ }^{b}$ myopia of spherical equivalent of 6 dioptres; ${ }^{c}$ vitreous liquefaction, vitreous bands; ${ }^{d}$ chorioretinal atrophy, retinal pigmentation, lattice degeneration, retinal breaks evisual acuity equal or better than $20 / 100$, ${ }^{\mathrm{e}}$ visual acuity worse than $20 / 100 ;{ }^{g}$ hand movement to light perception.

Ocular examination included best corrected visual acuity, refraction, applanation tonometry, biomicroscopy, indirect ophthalmoscopy and slit lamp biomicroscopy with the Goldman three-mirror. Eyes were considered to have simple myopia if the spherical equivalent was less than 6 dioptres and high myopia if the spherical equivalent was 6 dioptres or more.

Ocular abnormalities were detected in 22 family members (Fig. 1, Table I). In the first generation, the father was blind in both eyes because of retinal detachment. Of his 6 children, all but one had high myopia. Two of them (II-1, II-5) were blind in both eyes and 1 (II-6) was blind in one eye due to irreparable retinal detachment.

The third generation consisted of 9 family members of whom all but 1 were myopic. Six (III-3, III-4, III-5, III-6, III-7, III-9) had high myopia. Of the latter, 3 (III-4, III-6, III-7) were blind in both eyes and 1 (III-3) was blind in one eye because of irreparable retinal detachment. The fellow eye of the last patient also had retinal detachment which was operated on successfully. The fourth generation consisted of 26 family members, 8 of whom were myopic. Of these, 5 (IV-9, IV-11, IV-13, IV-15, IV21) had high myopia. One of them (IV-21) developed retinal detachment and was successfully operated on, and 1 (IV-13) was blind in both eyes due to irreparable retinal detachment.

Thus, out of a total of 42 family members 10 patients developed retinal detachment (Table II). In 8 of them the retinal detachment occurred in both eyes. Thus, a total of 18 eyes were affected. In 9 of 10 patients the retinal detachment had occurred up to the age of 30 years and in 7 of them before the age of 13 years (Tables II, IV). The retinal detachment occurred at the age of 60 years in only one eye. In this patient the detachment developed following cataract surgery. Following retinal detachment surgery, the retina remained attached in only 2 eyes, whereas in the other 16 it did not.

The systemic manifestations in this family have been described previously. ${ }^{8}$ All affected children and some affected adults had similar flat faces due to midface hypoplasia and retrognathia (Fig. 2). Only 2 of the affected siblings had cleft palate. ${ }^{8}$ None of the affected members had either clinical hearing defects or symptoms related to degenerative joint disease.

Table II. Onset of blindness or retinal detachment and the results of retinal detachment surgery

\begin{tabular}{|c|c|c|c|c|}
\hline \multirow{2}{*}{$\begin{array}{l}\text { Case no., } \\
\text { family member }\end{array}$} & \multirow[b]{2}{*}{ Age (years) } & \multirow{2}{*}{$\begin{array}{l}\text { No. of eyes } \\
\text { affected }\end{array}$} & \multicolumn{2}{|c|}{ Surgical results } \\
\hline & & & Failure & Success \\
\hline $1, \mathrm{I}$ & 30 & $\mathrm{OU}$ &,$+ \mathrm{OU}$ & \\
\hline 2. II-1 & 60 & $\mathrm{OU}$ &,$+ \mathrm{OU}$ & \\
\hline 3 , II-5 & 30 & OU &,$+ \mathrm{OU}$ & \\
\hline 4, II-6 & Childhood & 1 eye & + & \\
\hline 5, III-3 & $7 ; 40^{\mathrm{a}}$ & OU & + & + \\
\hline 6, III-4 & 6 & OU &,$+ \mathrm{OU}$ & \\
\hline 7, III-6 & 6 & OU &,$+ \mathrm{OU}$ & \\
\hline 8, III-7 & 6 & OU &,$+ \mathrm{OU}$ & \\
\hline 9, IV -13 & 7 & OU &,$+ \mathrm{OU}$ & \\
\hline 10, IV-21 & 6 & 1 eye & & + \\
\hline
\end{tabular}

OU, both eyes.

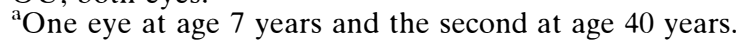




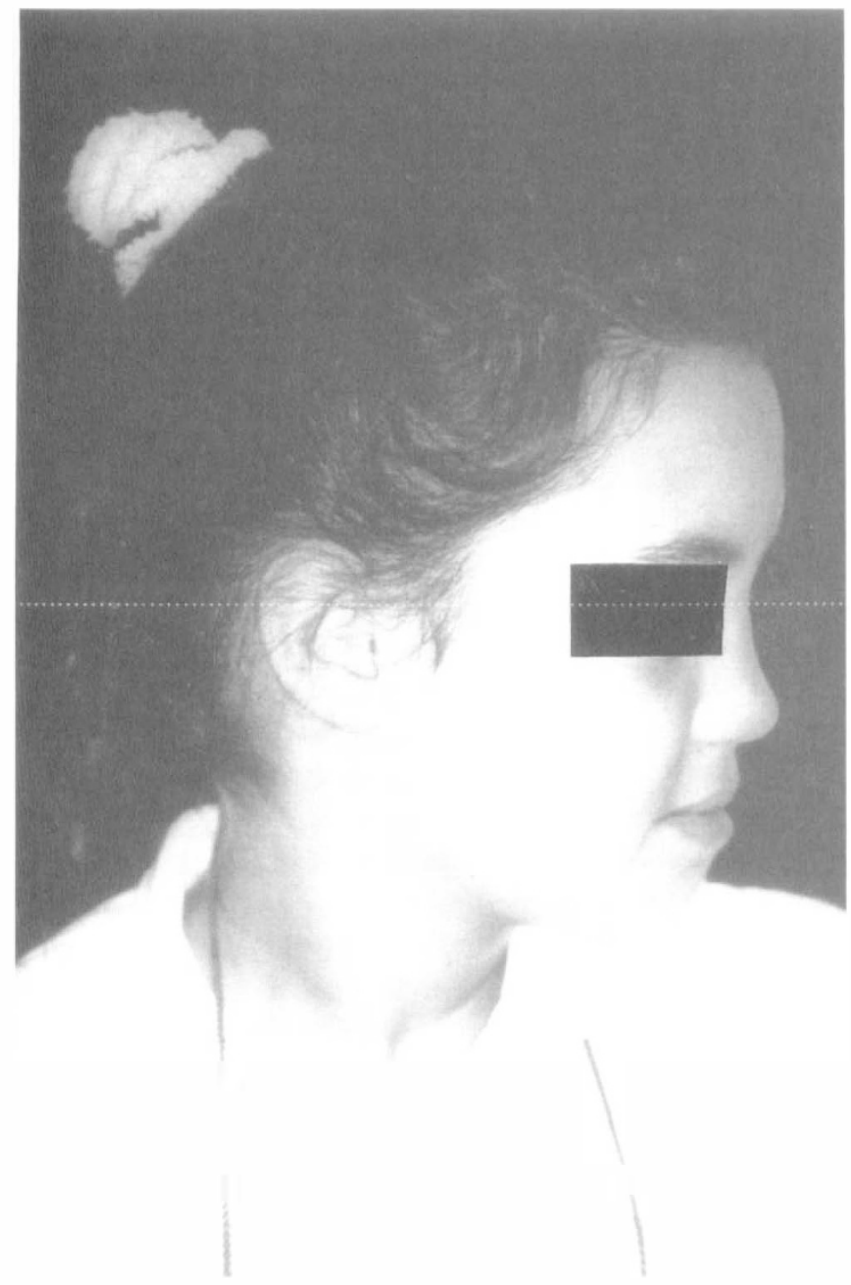

Fig. 2. An example of a family member with flat face and retrognathia.

Genetic linkage analysis of the family demonstrated a linkage to the gene $\mathrm{COL} 2 \mathrm{A1}{ }^{8}$

\section{Indications for Treatment}

\section{TREATMENT}

Indications for laser treatment were: (1) extensive peripheral retinal degeneration including an area of at least five contiguous hours of lattice degeneration with or without the presence of retinal breaks (Fig. 3), or (2) isolated foci of lattice degeneration with retinal breaks in the presence of at least one of the following known risk factors for retinal detachment: (a) a family member with inherited vitreoretinal disease, $(b)$ previous retinal detachment in the fellow eye, (c) a family history of retinal detachment, (d) myopia.

\section{Technique}

According to the retinal findings, one of two types of treatment was performed. One was called 'circumferential' treatment and it was given to eyes with extensive contiguous retinal lesions where the lesions were present in at least three quadrants of the retina
(Fig. 3). ${ }^{12}$ These eyes were treated with confluent laser burns $360^{\circ}$ around the peripheral retina. Four to eight rows of laser burns were applied circumferentially at the junction between the posterior border of the lesions and the unaffected retina (Fig. 3) ${ }^{12}$ Eyes in which lesions were located at the equator and/or posterior to it and were far from the ora serrata were given two to three rows of laser burns at the edge of the anterior border of the lesions, in addition to the burns applied at the posterior border of the lesions, to ensure chorioretinal adhesion around all the abnormal retina. The other type of treament was called 'focal' treatment. Focal treatment was applied in eyes with small localised lesions of lattice degeneration or with isolated breaks. In these eyes the lesion was encircled by three to six rows of burns. $^{11}$

In all cases the size of the burns was $300-500 \mu \mathrm{m}$ in diameter. The burns were put less than a quarter of a burn width apart for $0.1-0.2$ seconds at a power level adjusted to achieve moderate to heavy whitening of the retina (Fig. 3). ${ }^{10,12}$ The circumferential treatment was performed in either one or two sessions.

In all cases the laser was delivered through a slit lamp laser system. In young children the treatment was performed under general anaesthesia, as previously described. ${ }^{13}$ In brief, the child lay on a stretcher-bed next to the laser machine and was anaesthetised using a mobile anaesthetic unit. Following intubation the child was transferred from the stretcher-bed to the laser system in a sitting position on a mobile chair. The head was fixed to the slit lamp and treatment was carried out.

\section{Report of a Case}

\section{RESULTS}

Patient IV-11 was followed in our eye clinic from the age of 1 year because of her family history. The initial examination revealed myopia of 13.75 (spherical equivalent) in both eyes. Lattice degeneration was first observed when she was 4 years old in the peripheral retinas of both eyes. Over the next 3 years these lesions extended centrally and circumferentially. When she was 7 years old a hole was seen in an area of lattice degeneration at the superior temporal quadrant of the left eye. Because of the progression in retinal pathology, and in view of the family history, preventive laser photocoagulation was performed. Burns were applied all around the retina, both anterior and posterior to the areas of lattice. Six months later a hole was also seen in the fellow eye, and laser photocoagulation was applied circumferentially all around the peripheral retina. Seven years later both retinas are attached and vision is 20/40 in both eyes.

Twenty-two patients (44 eyes) had ocular manifestations of at least myopia; for one patient (I-1) 

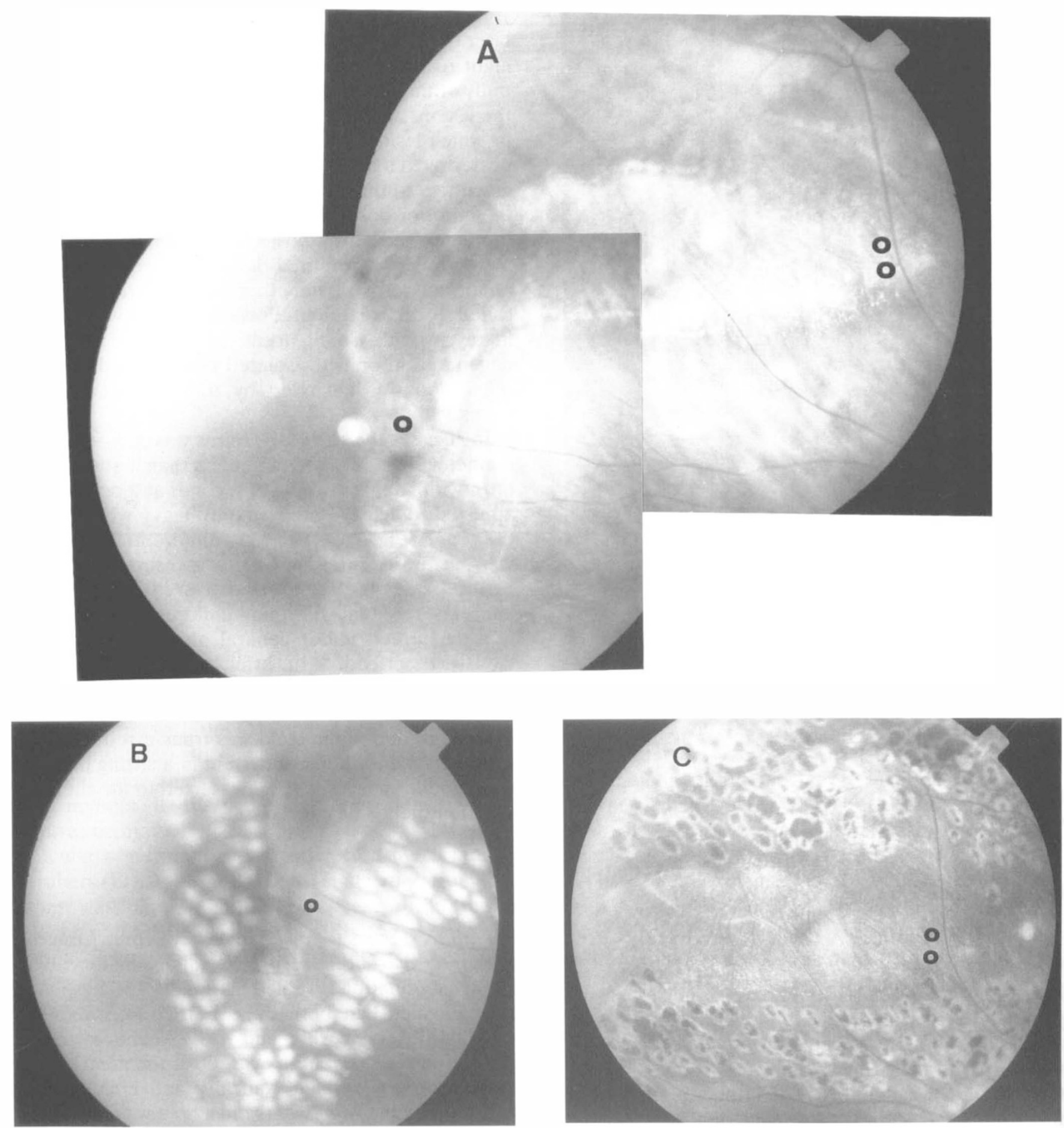

Fig. 3. Case IV-9. Ophthalmoscopic appearance before, immediately after and 1 year after laser treatment. (A) The reconstruction of the two figures demonstrates a large continuous lattice lesion. (B) Acute laser burns placed around the lattice lesion. (C) Laser scars cover the anterior and posterior borders of the lesion, 1 year after laser photocoagulation.

there was no exact information of the vitreoretinal status before retinal detachment had occurred. The other 21 patients (42 eyes) all had varying degrees of vitreoretinal degeneration defined by vitreous liquefaction, vitreous strands, retinal pigmentation, lattice degeneration and retinal breaks. Six patients (12 eyes) showed vitreous abnormalities with or without mild retinal pathology and none of them developed retinal detachment or received laser treatment (Table I). Ten patients (18 eyes; both eyes in 8 patients, one eye in each of 2 patients) developed retinal detachment due to severe vitreoretinal alterations (Tables I, II). In 6 patients (10 eyes: both eyes in 4 patients, one eye in each of 2 patients) laser treatment was indicated for retinal pathology (Tables I, III). 
Table III. Summary of the laser treatment

\begin{tabular}{|c|c|c|c|c|c|c|c|c|c|c|}
\hline \multirow{3}{*}{$\begin{array}{l}\text { Case no., } \\
\text { family member }\end{array}$} & \multicolumn{6}{|c|}{ Age (years) at treatment } & & & & \\
\hline & \multicolumn{2}{|c|}{ First } & \multicolumn{2}{|c|}{ Second } & \multicolumn{2}{|c|}{ Third } & \multicolumn{2}{|c|}{ Type of treatment } & \multicolumn{2}{|c|}{ Follow-up (years) } \\
\hline & $\mathrm{RE}$ & $\mathrm{LE}$ & $\mathrm{RE}$ & $\mathrm{LE}$ & $\mathrm{RE}$ & $\mathrm{LE}$ & $\mathrm{RE}$ & $\mathrm{LE}$ & $\mathrm{RE}$ & $\mathrm{LE}$ \\
\hline 1, III-2 & 28 & 28 & & 35 & & 37 & $\mathrm{C}$ & $\mathrm{F}$ & 15 & $8^{a}$ \\
\hline 2, III-5 & 31 & 35 & & & & & $\mathrm{~F}$ & $\mathrm{~F}$ & 9 & $5^{b}$ \\
\hline 3, IV -8 & 10 & & & & & & $\mathrm{~F}$ & & 3 & \\
\hline 4, IV -9 & 8 & & & & & & $\mathrm{C}$ & & 1 & \\
\hline 5, IV-11 & 7 & 7 & & & & & $\mathrm{C}$ & $\mathrm{C}$ & 7 & 7 \\
\hline 6, IV -15 & 12 & 13 & 12 & & & & $\mathrm{~F}$ & $\mathrm{~F}$ & 2 & 1 \\
\hline
\end{tabular}

C, circumferential; $F$, focal.

a Years of follow-up since last treatment.

${ }^{\mathrm{b}}$ The patient developed retinal detachment 5 years after laser treatment.

We evaluated the effects of laser treatment by comparing the incidence of retinal detachment between laser-treated (10 eyes) and non-treated (34 eyes) eyes in relation to the age of retinal detachment onset; we found that retinal detachment occurred significantly more frequently in non-lasered eyes, in particular if the detachment occurred before the age of 13 years (Table IV).

A total of 10 eyes of 6 family members (III-2, III-5, IV-8, IV-9, IV-11, IV-15) were treated in our clinic (Tables I, III). Focal treatment was applied in 6 of these eyes, and peripheral scatter photocoagulation in 4 (Table III).

After laser treatment, patients were followed for from 1 to 15 years. In 9 of 10 eyes the retinas remained attached during that period. Two of the 6 eyes that received focal treatment needed additional treatment because they had developed new retinal lesions; 1 eye (III-2) received two more treatments and the other (IV-15) received only one (Table III). One patient (III-5, two eyes) was lost to follow-up 6 months after the last focal laser treatment. Five years later he developed retinal detachment due to a new lesion in one eye. The detachment affected the whole retina except for the previously lasered area, which remained attached. The retina of the other eye of this patient remained attached.

Following laser treatment in all eyes, visual acuity was unaffected and no ocular complications were observed.

None of the 20 non-affected family members developed retinal abnormalities or detachment.

\section{COMMENT}

Stickler syndrome is a hereditary progressive arthro- ophthalmology. Common systemic features include typical facial changes, such as mid-facial hypoplasia, broad nasal ridge, micrognathia (Fig. 2) and cleft palate. ${ }^{1-2.7-9}$ Also common are epiphyseal dysplasia and premature degenerative joint disease, usually detectable only on radiological examination. Ocular manifestations include high myopia, strabismus, glaucoma, presenile cataract and vitreoretinal degeneration with a high incidence of retinal detachment, ${ }^{7-9}$ which is sometimes very difficult to repair. ${ }^{56.9 .14}$ The clinical expression of the disease is variable and the combination of abnormalities may be very different in different patients. ${ }^{8.9}$ Tight linkage to the gene COL2A1 was demonstrated in many families with Stickler syndrome. ${ }^{15.16}$ Mutation of this gene was described as well. ${ }^{17}$ Recently Snead et al. ${ }^{18}$ used two markers at the COL2A1 locus and found two distinct phenotypic and genetic subgroups of Stickler syndrome. Thus, it was suggested that the variability of the syndrome may be caused by different allelic mutations of the gene, or that several genes are responsible for Stickler syndrome. ${ }^{8}$ In a previous paper discussing genetic linkage analysis of three families with Stickler syndrome, it was concluded that the family described here most probably represents type 1 Stickler syndrome. ${ }^{8}$

The main ocular manifestations of Stickler syndrome in the family described here were congenital high myopia, vitreoretinal degeneration and a high incidence of retinal detachment, often at a young age (Table I). In this particular family, in 7 of 10 eyes retinal detachment occurred before puberty. Other authors found that retinal detachment developed more often in adolescents than in children. ${ }^{3,8}$ None of our patients had giant retinal tear. Nevertheless the

Table IV. A comparison of the incidence of retinal detachment between lasered and non-lasered eyes in relation to the age of retinal detachment

\begin{tabular}{|c|c|c|c|c|c|c|}
\hline \multirow[b]{2}{*}{$\begin{array}{l}\text { Retinal } \\
\text { status }\end{array}$} & \multicolumn{2}{|c|}{$\begin{array}{c}\text { Age } \leqslant 13 \text { years } \\
(n=25 \text { eyes })\end{array}$} & \multicolumn{2}{|c|}{$\begin{array}{c}\text { Age }>13 \text { years } \\
(n=19 \text { eyes })\end{array}$} & \multicolumn{2}{|c|}{$\begin{array}{c}\text { Total } \\
(n=44 \text { eyes })\end{array}$} \\
\hline & $\begin{array}{c}\text { Non-lasered eyes } \\
(n=19 \text { eyes })\end{array}$ & $\begin{array}{c}\text { Lasered eyes } \\
(n=6 \text { eyes })\end{array}$ & $\begin{array}{l}\text { Non-lasered eyes } \\
(n=15 \text { eyes })\end{array}$ & $\begin{array}{l}\text { Lasered eyes } \\
(n=4 \text { eyes })\end{array}$ & $\begin{array}{c}\text { Non-lasered eyes } \\
(n=34 \text { eyes })\end{array}$ & $\begin{array}{l}\text { Lasered eyes } \\
(n=10 \text { eyes })\end{array}$ \\
\hline Attached retina & 13 & 6 & 6 & 3 & 19 & 9 \\
\hline Detached retina & 6 & 0 & \multicolumn{2}{|c|}{$p<0.05$} & \multicolumn{2}{|c|}{$p<0.025$} \\
\hline
\end{tabular}

Values are the number of eyes. 
results of retinal detachment surgery in our series were poor, as described by others as well. ${ }^{9}$ Most of the patients in this series who developed retinal detachment became blind in one or both eyes (Table I). In view of the inauspicious familial pattern and the reported data of a high incidence of retinal detachment with poor surgical results in patients with Stickler syndrome, preventive treatment for retinal detachment for members exhibiting progressive vitreoretinal degeneration was suggested. The question then arose what type of treatment should be performed.

Preventive treatment for retinal detachment may include: (1) releasing vitreoretinal traction by scleral buckling and/or vitrectomy and/or (2) creating a chorioretinal adhesion around retinal breaks and/or around precursors of retinal breaks by cryotherapy or photocoagulation. ${ }^{19}$ Of the available methods we chose to produce chorioretinal adhesions by laser photocoagulation, a non-invasive technique. Recent experimental studies have shown that cryotherapy may cause dispersion of viable pigment epithelial cells through the retinal break into the vitreous cavity. ${ }^{20}$ It also causes breakdown of the bloodretinal barrier with leakage of serum proteins into the intraocular fluid. ${ }^{21}$ Some of the serum components may lead to cellular migration and proliferation. The combination of both, or each of them separately, may in humans as well as in animal models, contribute to subsequent epiretinal formation.

We also were encouraged to use laser photocoagulation by our good results with argon laser photocoagulation as a preventive treatment for retinal detachment in: (1) eyes with symptomatic retinal tears, ${ }^{11}$ (2) patients with breaks in one eye and a history of retinal detachment in the fellow eye, ${ }^{11}$ (3) eyes at high risk for developing retinal detachment ${ }^{12}$ and (4) members of a family with snowflake vitreoretinal degeneration. ${ }^{10}$ The last is a disease characterised by vitreoretinal pathology and a high incidence of retinal detachment with poor surgical outcome.22 Affected family members with snowflake vitreoretinal degeneration who exhibited progressive peripheral retinal changes received either focal (for limited pathology) or confluent (for extensive changes) circumferential argon laser photocoagulation. ${ }^{10}$ Over a lengthy follow-up period of up to 19 years, none of the treated eyes with snowflake vitreoretinal degeneration had developed retinal detachment. This led us to use these methods in patients with Stickler syndrome as well, where the type of treatment employed depended on the extent of retinal pathology.

In general, in cases where retinal breaks, or areas of vitreoretinal abnormality that are judged likely to be the site of retinal break formation, are localised, laser burns can be directed around each individual lesion. This type of treatment is called focal treatment. Another possibility is that a broad zone of confluent peripheral chorioretinal adhesions can be formed over $360^{\circ}{ }^{19}$ This method is used only rarely in selected cases. ${ }^{19}$ In the family presented here we used both methods. In cases where the pathology was limited to one or a few localised areas, focal treatment around the lesions was applied. In eyes where the pathology was extensive (as shown in Fig. 3) and the lesions were almost contiguous, a confluent, circumferential $360^{\circ}$ treatment was employed. The rationale for such a treatment is that the summation of multiple focal treatments around each individual lesion led to almost continuous laser scars apart from small unaffected areas. Thus, we assumed that a continuous line of chorioretinal adhesion is preferable to a noncontinuous adhesion that leaves small zones of possible vitreoretinal traction between treated areas, which subsequently may be complicated by retinal detachment. Further, a continuous line may prevent central progression of peripheral retinal detachment if it occurs. It should be pointed out that in this family, in cases where the lesions were located posteriorly, at a marked distance from the ora, laser burns were also placed at the anterior border of the lesions to ensure firm chorioretinal adhesions around all pathological areas that might develop retinal detachment. In the 4 eyes that received the confluent circumferential type of treatment, the retinas have remained attached for a follow-up period ranging from 1 to 15 years, and none of the patients has developed any ocular complications (Table III). Four patients (6 eyes) received focal treatment. In 3 patients (4 eyes) the retinas have remained attached for a follow-up period of 1 to 15 years and no ocular complications have developed. The fourth patient ( 2 eyes) was lost to follow-up 6 months after his last treatment. Five years later he developed retinal detachment in one eye resulting from a new untreated lesion whereas the lasered area remained attached. The retina of his other eye remained attached. The fact that an untreated lesion had progressed to retinal detachment may provide indirect support for the efficacy of laser treatment, since none of the treated patients progressed to retinal detachment, even those who had developed new lesions and were re-treated. Obviously one cannot know how many of the treated eyes would have developed retinal detachment if they had been left untreated. However, since a significantly higher incidence of retinal detachment was found in non-lasered than lasered eyes (Table IV), it seems reasonable to assume that retinal detachment would have occurred in at least some of them had they been untreated. 
It should, however, be emphasised that laser treatment in this study was neither intended nor expected to prevent formation of new peripheral lesions. The occurrence of new tears in areas that appear clinically normal ${ }^{23-28}$ and in prophylactically treated eyes ${ }^{28}$ has been described previously. The new lesions do not appear to be directly associated with the lasering procedure. ${ }^{28}$ Indeed, in 2 of the patients new lesions observed after the initial treatment were treated with laser and the retinas remained attached (Table III). When chorioretinal adhesions are created to prevent retinal detachment, the adhesions tend to separate the anterior and posterior parts of the retina and thus to halt progression of posterior retinal detachment. ${ }^{19}$ However, in most cases the ophthalmoscopic appearance following lasering is an attached retina and not an area of detached retina encircled by laser marks. Thus, it seems that the lasering may have an additional effect which, by creating the firm chorioretinal adhesions, may offset vitreoretinal traction and form a 'new healthy ora'. A randomised prospective study to evaluate the efficacy of laser photocoagulation in this group of patients is needed. However, it is a rare disease with a high incidence of retinal detachment and unusually poor surgical results. $^{7}$ The data described here increase our knowledge of this topic. They may also provide some guidelines for treating patients with progressive vitreoretinal pathology, until results of a clinical trial are available.

In view of the high incidence of retinal detachment and the poor surgical outcome, it may be justifiable in cases of Stickler syndrome with extensive vitreoretinal pathology to widen the indications for treatment, as has been suggested by others for this syndrome ${ }^{5,7}$ and for other similar diseases, ${ }^{20,29}$ and to include also round holes, which are generally considered to be innocuous. Young patients with Stickler syndrome should be carefully followed so that new lesions can be detected and prophylactic treatment can be considered.

Key words: Laser photocoagulation, Prophylactic treatment, Retinal detachment, Stickler syndrome.

\section{REFERENCES}

1. Stickler GB, Belau PG, Farrell FJ, Jones JD, Pugh DG, Steinberg, AG, Ward LE. Hereditary progressive arthro-ophthalmopathy. Mayo Clin Proc 1965;40: 433-55.

2. Stickler GB, Pugh DG. Hereditary progressive arthroophthalmopathy. II. Additional observations on vertebral abnormalities, a hearing defect, and a report of a similar case. Mayo Clin Proc 1967;42:495-500.

3. Opitz JM, France T, Herrmann J, Spranger JW. The Stickler syndrome. N Engl J Med 1972;286:546-7.

4. Herrmann J, France TD, Spranger JW, Opitz JM, Wifler C. The Stickler syndrome (hereditary arthroophthalmopathy). Birth Defects 1975;11:76-103.
5. Blair NP, Albert DM, Liberfarb RM, Hirose T. Hereditary progressive arthro-ophthalmopathy of Stickler. Am J Ophthalmol 1979;88:876-88.

6. Maumenee IH. Vitreoretinal degeneration as a sign of generalized connective tissue diseases. Am J Ophthalmol 1979;88:432-49.

7. Temple IK. Stickler's syndrome. J Med Genet 1989;26: 119.

8. Zlotogora J, Sagi M, Schuper A, Leiba H, Merin S. Variability of Stickler syndrome. Am J Med Genet 1992:42:337-9.

9. Robertson JE, Meyer SM. Hereditary vitreoretinal degenerations. In: Ryan's retina textbook. Vol. 1. St Louis: CV Mosby, 1989:474-6.

10. Pollack A, Uchenik D, Chemke J, Oliver M. Prophylactic laser photocoagulation in hereditary snowflake vitreoretinal degeneration. Arch Ophthalmol 1983;101:1536-9.

11. Pollack A, Oliver M. Argon laser photocoagulation of symptomatic flap tears and retinal breaks of fellow eyes. Br J Ophthalmol 1981;65:469-72.

12. Pollack A, Milstein A, Oliver M, Zalish M. Circumferential argon laser photocoagulation for prevention of retinal detachment. Eye 1994;8:419-22.

13. Pollack A, Leiba H, Soroker D, Ezri T, Merelis P, Oliver M. Laser treatment of eye disorder in children. J Pediatr Ophthalmol Strabismus 1991;28:333-7.

14. Ferrone PJ, McCuen BW II, de Juan E Jr, Machemer $\mathrm{R}$. The efficacy of silicone oil for complicated retinal detachments in the pediatric population. Arch Ophthalmol 1994;112:773-7.

15. Francomano CA, Liberfarb RM, Hirose T, Maumenee IH, Streeten EA, Meyers DA, Pyeritz RE. The Stickler syndrome: evidence for close linkage to the structural gene for type II collagen. Genomics 1987;1:293-6.

16. Knowlton RG, Weaver EJ, Struyk AF, Knobloch WH, King RA, Norris K, et al. Genetic linkage analysis of hereditary arthro-ophthalmopathy (Stickler syndrome) and the type II procollagen gene. Am J Hum Genet 1989;45:681-8.

17. Ahmad NN, Ala-Koko L, Knowlton RG, Weaver EJ, Maguire JI, Tasman W, Prockop DJ. A stop codon in the gene for type II collagen (COL2A1) causes one variant of arthro-ophthalmopathy (the Stickler syndrome). Am J Hum Genet 1990;47:A206.

18. Snead MP, Payne SJ, Barton DE, Yates JRW, AlImara L, Pope FM, Scott JD. Stickler syndrome: correlation between vitreoretinal phenotypes and linkage to COL2A1. Eye 1994;8:609-14.

19. Micheles RG, Wilkinson CP, Rice TA. Prevention of retinal detachment. In: Retinal detachment textbook. St Louis: CV Mosby, 1950:1059, 1098-108.

20. Campochiaro PA, Maden IH, Vidaurri-Leal J, Glaser $\mathrm{BM}$. Cryotherapy enhances intravitreal dispersion of viable retinal pigment epithelial cells. Arch Ophthalmol 1985;103:343-6.

21. Jaccoma EH, Conway BP, Campochiaro PA. Cryotherapy causes extensive breakdown of the blood-retinal barrier. Arch Ophthalmol 1985;103:1728-30.

22. Hirose T, Lee KY, Schepens CL. Snowflake degeneration in hereditary vitreoretinal degeneration. Am J Ophthalmol 1974;77:143-53.

23. McPherson A, O'Malley R, Beltangady SS. Management of the fellow eyes of patients with rhegmatogenous retinal detachment. Ophthalmology 1981; 88:922-34.

24. Byer NE. Long-term natural history of lattice degeneration of the retina. Ophthalmology 1989;96:1396-402. 
25. Schepens CL. The preventive treatment of idiopathic and secondary retinal detachment. In: Acta XVIII Concilium Ophthalmologicum (Belgium) 1958;1: 1019-27.

26. Delaney WV, Oates RP. Retinal detachment in the second eye. Arch Ophthalmol 1978;96:629-34.

27. Foos RY. Post-oral peripheral retinal tears. Ann Ophthalmol 1974;6:679-87.
28. Folk JC, Bennett SR, Klugman MR, Arrindell EL, Boldt HC. Prophylactic treatment to the fellow eye of patients with phakic lattice retinal detachment: analysis of failures and risks of treatment. Retina 1990; 10:165-9.

29. van Balen ATM, Falger ELF. Hereditary hyaloidretinal degeneration. Arch Ophthalmol 1970; 83:152-62. 